\title{
Çanakkale ilinde Bulunan Ortaöğretim Okullarında Görev Yapan Öğretmenlerin İş Güvenliği Bilgi Düzeylerinin Değerlendirilmesi *
}

\author{
Evaluation of Occupational Safety Knowledge Levels of Teachers \\ Working at Secondary Schools in Çanakkale
}

Adem ERGÜL (D) , Burcu MESTAV (D) , Ömer Faruk ÖZTÜRK

\begin{abstract}
ÖZET
Bu çalışmada, Çanakkale ilinde bulunan ortaöğretim okullarında görev yapan öğretmenlerin iş güvenliği bilgi düzeyleri, farklı demografik özellikleri dikkate alınarak değerlendirilmiştir. Çalışma kapsamında nicel araştırma tekniklerinden kaynak tarama ile yeni bir ölçek hazırlanmış ve bu ölçek katılımcılara anket tekniği ile sunulmuştur. Anket verileri SPSS 24.0 paket programı ile analiz edilmiş, erkek öğretmenlerin iş sağlığı ve iş güvenliği bilgi düzeylerinin kadın öğretmenlere göre daha yüksek olduğu gözlemlenmiștir. Ayrıca, öğretmenlerin hizmet yıllarındaki artışla iş sağlığı ve güvenliği bilgi düzeylerinin de arttığı gözlemlenmiștir.

Anahtar Kelimeler: İș Sağlığı ve Güvenliği, Ortaöğretim Okulları, Çalışan Sağlığı, İş Güvenliği, Farkındalık.
\end{abstract}

\section{ABSTRACT}

In this study, the occupational safety knowledge levels of teachers working in secondary schools in Çanakkale province were evaluated considering different demographic characteristics. Within the scope of the study, a new scale was prepared by scanning the resources from quantitative research techniques and this scale was presented to the participants with the questionnaire technique. The survey data were analyzed with the SPSS 24.0 package program, and it was observed that the occupational health and safety knowledge levels of male teachers were higher than female teachers. In addition, it was observed that the occupational health and safety knowledge levels of teachers increased with the increase in their years of service.

Keywords: Occupational Health and Safety, Secondary Schools, Employee Health, Occupational Safety, Awareness.

Adem ERGÜL I ademergul63@gmail.com

Çanakkale İl Milli Eğitim Müdürlüğü, Çanakkale, Türkiye

Çanakkale Provincial Directorate of National Education, Çanakkale, Turkey

Burcu MESTAV I burcumestav@comu.edu.tr

Çanakkale Onsekiz Mart Üniversitesi, Fen Edebiyat Fakültesi, Çanakkale, Türkiye

Çanakkale Onsekiz Mart University, Faculty of Arts and Sciences, Çanakkale, Turkey

Ömer Faruk ÖZTÜRK | ofozturk@comu.edu.tr | Sorumlu Yazar/Corresponding Author Çanakkale Onsekiz Mart Üniversitesi, Fen Edebiyat Fakültesi, Çanakkale, Türkiye Çanakkale Onsekiz Mart University, Faculty of Arts and Sciences, Çanakkale, Turkey 


\section{GİRIŞ}

Ülkemizde yaşanan iş kazaların en fazla tehlikeli hareketler diye nitelendirilen ve eğitimsizlik, işi önemsememe, ihmal gibi kişisel sebeplerden meydana geldiği söylenebilir. İSG kültürünün yaygınlaştırılması yaralanma veya ölüm gibi olumsuzlukların ortadan kaldırılmasında büyük önem arz etmektedir [1].

2018-2019 Eğitim Öğretim yllındaki öğretmen ve öğrenci sayısı 19.186.167 kişidir [2]. Nüfusumuz ise 83.154.997 kişidir [3]. Bu verilere göre nüfusumuzun \% 23 'ünü oluşturan geleceğin çalışanları ve işverenleri olacak öğrencilerimiz ve onların sorumluluğunu üstlenen öğretmenlerimiz göz önüne alındığında, okullarda İSG ile ilgili yapılacak çalışmaların İSG kültürünün oluşturulmasında ne kadar önemli olduğu ortaya çıkmaktadır.

Ersoy, çalışmasında örneklem grubunu sanayideki işletmelerde stajını yapan son sınıf meslek lisesi öğrencilerin İSG ile ilgili karşılaşmış oldukları problemler hakkında bazı tespitlerde bulunmuştur. Araştırma sonucunda problemin kaynağını iş güvenliği kavram ve kurallarına yeteri kadar eğitim uygulamalarında yer verilmediğini ve çalışanların çalışma şartları hakkında bilgi sahibi olmadıklarını söylemiştir. Bununla birlikte staja gönderilen öğrencilerin meslekte çalışabilme yeterliliğini belirlemek için onlara psikolojik ve fiziksel muayene yapılmasını, öğrencilerin işletmelerde karşılaşabilecekleri çalışma şartları hakkında iş güvenliği yönergesi verilmesi gerektiğini belirtmiştir [4].

Sekmen, 2005-2006 öğretim yılında "Anadolu Meslek, Endüstri Meslek, Teknik lise ve Anadolu Teknik Liseleri Elektrik Bölümleri”nde öğrenim gören 274’ü Öğrenci ve 86 ’sı Elektrik bölümü öğretmenlerine anket tekniğini kullanarak araştırma yapmıştır. Elektrik bölümünün diğer bölümlere göre ölüm ile sonuçlanabilecek elektrik çarpması durumunun yüksek olduğu, bu durumun öğrenci ve öğretmenler açısından önemli bir problem olduğu ayrıca problemin en aza indirilmesini sağlamak için birinci sınıftan itibaren ilk yardım eğitimi ve İSG eğitimleri verilmesinin gerekli olduğu ifade edilmektedir [5].

Yaman, Gaziantep’teki Meksa - Gesop Çıraklık Eğitimi Merkezindeki Kursiyerlerin İş Sağlığı ve İş Güvenliğine Bakışı çalışmasında öğrencilerin İSG farkındalık durumlarını, iş kazası geçirme, meslek hastalığına yakalanma durumlarını evrenden küme örnekleme ile 969 öğrenciye anket tekniğini kullanarak uygulamıştır. Bu çalışmanın sonucunda eğitim merkezine devam eden ve gelecekte bir işgören olarak sahada işini icra edecek olan öğrencilerde İSG ile ilgili temel uygulamalarda belirli bir bilinç düzeyi oluşturulması ve bu bilincin uygulamada ortaya konulması için desteklenmesi gerektiğini belirtmiştir. İşveren ve yöneticilerin işletmelerdeki güvensiz koşulları ve güvensiz davranışları ortadan kaldırmak için çalışanlara eğitimler vererek, iş kazalarını buz dağına benzeterek buz dağının sadece bilinen kısmını değil, bilinmeyen kısmını da yok edilebileceğini belirtmiştir [6].

Aksoy ve ark., çalışmalarında; İSG bilincinin meslek yüksekokulu öğrencilerinde oluşturulabilmesi için gerek işletmeler gerekse eğitim kurumlarına önemli sorumlulukların düştüğünü, ayrıca öğrencilerin çalışma hayatına başlamadan önce meslek hastalıkları ve iş kazaları hakkında bilgilendirilerek İSG bilincinin oluşturulmasının gerekliliğinden bahsedilmektedir [7].

Tepebaş, Ordu, Giresun, Trabzon ve Samsun illerinde acil servis çalışanlarının iş güvenliği konusunda algılama düzeylerini belirlemek amaciyla 471 kişiye anket uygulamıştır. Araştırmasında işçilerin çoğunluğu iş riski ya da İSG eğitimi aldıklarını ifade etmiştir. İş kazası geçirmeyenlerin oranını daha yüksek olduğunu ortaya koymuştur. 
Çalışanların iş güvenliği algılarının sadece cinsiyetlerine, işyerinde çalışıkları bölümde, baktıkları hasta sayısına, eğitim durumlarına, iş sağlığı ve güvenliği eğitimi almaları ya da almamaları durumlarına, herhangi bir iş kazası geçirmeleri veya geçirmemelerine göre farklılık gösterdiğini bulmuştur [8].

Gümüş, okullarda iş sağlığı ve güvenliği uygulamaları ve öğretmenlerin bu konudaki bilgi düzeylerinin irdelenmesi çalışmasında genel olarak öğretmenlerin İSG kanunu hakkında kısmen bilgiye sahip oldukları, İSG konusunda çoğu öğretmenlerin bilgilendirilmediği, çalıştıkları okullarda uzman kişiler tarafından İSG ile ilgili bilgilendirmelerin yapılmadığı sonucuna varmıştır [9].

Beşir, çalışmasında okullarda çalışan gönüllü 125 öğretmene anket uygulayarak yapmıştır. Çalışmasının neticesinde öğretmenlerin İSG konusunda bilgi düzeylerinin yetersiz olduğunu, yetersiz olan bilgi düzeylerini ise yapılacak ISG eğitimleri ile farkındalıklarını geliştirilebileceğinin önemine vurgu yapmıştır [10].

Uzuntarla, hizmet vermekte olan bir eğitim ve araştırma hastanesinde görev yapan çalışanlardan 418 kişi ile anket tekniği ile çalışanların iş güvenliği farkındalıkları ve güvenli davranışları arasındaki ilişkilerini incelemişsir. $\mathrm{Bu}$ inceleme sonucunda sağlık çalışanlarının iş güvenliği farkındalıkları ile güvenli davranış düzeylerinin yüksek olduğunu, iş güvenliği farkındalığının gelir düzeyine göre farklılık gösterdiğini, iş güvenliği farkındalığı ile güvenli davranışlar arasında pozitif yönlü anlamlı ilişkinin olduğunu, iş güvenliği farkındalığının artması çalışanlarda güvenli davranışlar sergilemelerinde bir artş̧a neden olduğu sonucuna varmışıtır [11].

Yar, çalışmasında tehlikeli sınıfta bulunan plastik enjeksiyon ve otomobil parçası üretimi yapan bir fabrikanın 170 çalısanına uyguladığı ankette İSG farkındalığı arttırmak için, eğitim ve diğer İSG uygulamalarının etkisini incelemiştir. İnceleme sonunda İSG eğitimlerinin İSG farkındalığı oluşturmakta tek başına yetersiz kaldığını, İSG farkındalığını bir kültür haline dönüştürebilmek için bir takım teşvik ve cezai yaptırımlardan, uyarı işaretlerinden yararlanılabileceğini belirtmiştir [12].

Sarı, petrol rafinerisi çalışanlarının iş güvenliğine ilişkin görüşlerinin analizi çalışmasında çalışanların İSG’ye yönelik bilgi düzeylerinin orta düzeyde olduğu, cinsiyet açısından bir farklılığın olmadığı, yaş seviyeleri bakımından anlamlı bir farklılığın olduğu sonucunu tespit etmiştir [13].

\section{YÖNTEM}

\section{A. Araştırmanın Amacı}

Bu çalışmanın amacı, Çanakkale ili merkez ve ilçelerinde ortaöğretim okullarında görev yapan öğretmenlerin yürürlükte olan İSG mevzuatının getirdiği düzenlemeler ve yükümlülüklere ilişkin iş güvenliği bilgi düzeylerinin belirlenmesi, belirlenen bu bilgi düzeylerinin demografik özelliklerine göre farklılık gösterip göstermediğinin araştırılmas1 üzerinedir.

Çalışma için 20/02/2019 tarih ve 60305806-44E.3530043 numarası ile Çanakkale İl Milli Eğitim Müdürlüğü Anket-Araştırma İnceleme Komisyonu tarafindan onay alınmıştır.

\section{B. Araştırmada Kullanılan Yöntem}

Bu araştırmada İSG mevzuatı hakkında kanun ve yönetmelikler araştrılarak bilgiler toplanmış ve bu bilgiler doğrultusunda bir takım anket soruları hazırlanmıştır. Çalışma, bir alan çalışması olup, nicel araştırma tekniklerinden anket tekniği kullanılarak katılımcılarla bire bir görüşülerek yapılmışıır. Çalışma sonucunda elde edilen veriler, "SPSS (IBM SPSS Statistics 24) programi” kullanilarak analiz edilmiştir. 
Araştırmanın evrenini Çanakkale ili merkez ve ilçelerinde ortaöğretim okullarında görev yapan öğretmenlerin tamamı (N=1600) oluşturmuş olup, araştırmanın örneklemini \%95 güven düzeyine göre 463 Öğretmen (Kadın=260, Erkek=197, Cinsiyetini Belirtmeyen=6 kişi) oluşturmuştur. Araştırmanın neticesinde öğretmenlerin farklı demografik (cinsiyet ve yaş seviyeleri) özelliklerine göre İSG ile ilgili bilgi düzeyleri değerlendirilmiştir.

\section{Araştırmanın Kapsamı ve Sınırlıkları}

Bu araştırmada kullanılan İş Sağlığı ve Güvenliği farkındalık anketi “2018-2019 Eğitim-Öğretim Yılı”nda Çanakkale merkez ve ilçelerinde ortaöğretim okullarında görev yapan öğretmenlere uygulanmıştır. Araştırmamız Çanakkale ilinde liselerde görev yapan öğretmenler ile sınırlı tutulmuştur.

\section{BULGULAR}

Araştırmada katılımcılardan elde edilen bulgular dört bölümde analiz edilmiştir.

\section{A. Katılımcılara Ait Demografik Bulgular}

Araştırma kapsamında hazırlanan İSG farkındalık anketine, “2018-2019 Eğitim Öğretim Yılı”nda Çanakkale merkez ve ilçelerinde ortaöğretimde görev yapan 463 öğretmen katılmış olup, yapılan anketlerin tümü geçerli kabul edilmiştir. Demografik özelliklere ait özet bilgiler Tablo 1 'de verilmiştir.

\section{B. Anket Sorularına İlişkin Bulgular}

Çalışma sonucunda elde edilen veriler, "SPSS (IBM SPSS Statistics 24) programı” kullanılarak analiz edilmiştir. Çalışmada kullanılan değişkenlere ait tanımlayıcı istatistikler frekans, aritmetik ortalama, standart hata, ve yüzde ölçüleri kullanılarak değerlendirilmiştir. Verilerin normal dağılım gösterip göstermediği ve varyansların homojenliği
Tablo 1: Katılımcılara ait demografik yapı

\begin{tabular}{llcc}
\hline & Değişken & Frekans (n) & Yüzde (\%) \\
\hline \multirow{4}{*}{ Anket sayısı } & Geçerli & 463 & 100,0 \\
& Geçersiz & 0 & 0,0 \\
& Toplam & 463 & 100,0 \\
\hline \multirow{4}{*}{ Cinsiyet } & Kadın & 260 & 56,2 \\
& Erkek & 197 & 42,5 \\
& Belirtilmemiş & 6 & 1,3 \\
& Toplam & 463 & 100,0 \\
\hline \multirow{4}{*}{ Medeni Durum } & 365 & 78,8 \\
& Evli & 83 & 17,9 \\
& Bekar & 15 & 3,2 \\
& Belirtilmemiş & 463 & 100,0 \\
\hline \multirow{4}{*}{ Yaş Seviyeleri } & Toplam & 64 & 13,8 \\
& $22-32$ & 206 & 44,5 \\
& $33-43$ & 161 & 34,8 \\
& $44-54$ & 31 & 6,7 \\
& $55-65$ & 1 & 0,2 \\
& Belirtilmemiş & 463 & 100,0 \\
& Toplam & &
\end{tabular}

varsayımları kontrol edilmiştir. Çalışmada ortalamaları karşılaştırmak için parametrik testlerden iki seviyeli değişkenin bulunduğu sorular için t-testi, ikiden fazla seviyeli değişken arasında herhangi anlamlı bir farklılığın olup olmadığını karşılaştırmak için tek yönlü varyans (One-Way Anova) analizi kullanılmıştır. Anova testi sonrasında istatistiksel düzeyde anlamlı farklılığın hangi seviyeler arasında olduğunu tespit etmek için ortalamaların karşılaştırılması için geliştirilen Post Hoc testlerden Duncan testi uygulanmıştır. İki ya da ikiden fazla kategorik değişkenler arasındaki farklılığın belirlenmesi için ise çapraz tablo kullanılmıştır.

Anket güvenirliliği, güvenirlilik katsayısı cronbach's alpha $(\alpha)$ ile ifade edilmektedir. Güvenirlilik katsayısı çoğunlukla 0 ve +1 aralığında bir değer alır. Bu değer 1'e ne kadar yakın olursa, güvenirliğinde arttığı anlamına gelmektedir. $\alpha$ değeri:

0,00 ile 0,40 arasında ise güvenilir olmadığı, 0,40 ile 0,60 arasında ise düşük derecede güvenilir olduğu, 0,60 ile 0,90 arasında ise oldukça güvenilir olduğu, 0,90 ile 1,00 arasında ise yüksek derecede güvenilir olduğu ifade edilir [14]. 


\section{Anket Sorularına İlişkin Bağımsız T-Testi Analizi}

Katılımcılara sorulan soruların demografik değişkenlerden cinsiyet değişkenine göre farklılı̆̆ın anlamlı olup olmadığını çözümlemek için, Independent-Samples (Bağımsız Örneklem) t-testi kullanılmıştır. Her soru için $\mathrm{H} 0$ ve $\mathrm{H} 1$ hipotezi kurulmuştur. Soruların analizinden elde edilen p değeri > 0,05 olduğunda H0 hipotezi kabul edilir. Eğer p değeri < 0,05 olduğunda ise; H0 hipotezi reddedilir ve iki grup ortalamalar arası fark istatistiksel olarak anlamlı bulunur.

"İş kazası sonucunda ne yapılması gerektiği hakkında bilgi düzeyinin”, cinsiyet değişkenine göre farklılık gösterip göstermediği bakımından kurulan hipotez sonucunda elde edilen veriler Tablo 2'de verilmiştir.

Tablo 2: Katılımcıların iş kazası sonucunda ne yapılması gerektiği sorusunun cinsiyete göre farklılığının incelendiği bağımsız t-testi sonucu

\begin{tabular}{|c|c|c|c|c|}
\hline Cinsiyet & $n$ & $\bar{x}$ & $\begin{array}{c}\text { Standart Hata } \\
\text { (Std. Error) }\end{array}$ & p \\
\hline Kadın & 260 & 2,800 & 0,445 & \multirow{2}{*}{0,017} \\
\hline Erkek & 196 & 3,005 & 0,538 & \\
\hline
\end{tabular}

Soru analizinde elde edilen p değeri 0,017 bulunmuş olup bu soru için cinsiyet değişkeni bakımından istatistiksel olarak anlamlı bir fark tespit edilmiştir $(\mathrm{p}<0,05)$. Erkek öğretmenlerin puan ortalaması $(3,005 \pm 0,538)$ kadın öğretmenlerin puan ortalamasından $(2,800 \pm 0,445)$ büyük olduğu için erkeklerin kadınlara göre iş kazaları sonucunda ne yapmaları gerektiği hususunda daha fazla bilgiye sahip oldukları ifade edilebilir.

"Okulunuzdaki iş güvenliği ile ilgili riskler hakkında bilgi düzeyi” sorusunun cinsiyete göre anlamlı bir farklılık gösterip göstermediği bakımından yapılan analiz sonucunda elde edilen sonuçlar Tablo 3'de verilmiştir.
Tablo 3: Öğretmenlerin okullarındaki iş güvenliği ile ilgili riskler hakkında bilgi düzeylerinincinsiyete göre farklılıklarının değerlendirildiğibağımsız t-testi sonucu

\begin{tabular}{lcccc}
\hline Cinsiyet & $\mathbf{n}$ & $\overline{\mathbf{x}}$ & $\begin{array}{c}\text { Standart Hata } \\
\text { (Std. Error) }\end{array}$ & $\mathbf{p}$ \\
\hline Kadın & 260 & 2,903 & 0,652 & 0,003 \\
Erkek & 196 & 3,096 & 0,645 & \\
\hline
\end{tabular}

Soru analizinde elde edilen p değeri 0,003 bulunmuş olup bu soru için cinsiyet anlamında istatistiksel olarak anlamlı bir fark tespit edilmiştir $(p<0,05)$. Erkek öğretmenlerin puan ortalaması $(3,096 \pm 0,645)$, kadın öğretmenlerin puan ortalamasından $(2,903 \pm 0,652)$ daha büyük olduğu için erkek katılımcıların, kadın katılımcılara oranla fazla bilgiye sahip oldukları saptanmıştır.

"Eğitimci olarak iş güvenliği kurallarına gereken hassasiyetleri gösteriyorum" sorusunun cevabı cinsiyet bakımından anlamlı bir farklılık yoktur (H0) ile anlamlı bir farklılık vardır (H1) hipotezleri için yapılan analiz sonucunda elde edilen değerler Tablo 4’de verilmiştir.

Tablo 4: Katılımcıların eğitimci olarak iş güvenliği kurallarına hassasiyet göstermelerinin cinsiyete göre farklılığının değerlendirildiği bağımsız t-testi sonucu

\begin{tabular}{lcccc}
\hline Cinsiyet & $\mathbf{n}$ & $\overline{\mathbf{X}}$ & $\begin{array}{c}\text { Standart Hata } \\
\text { (Std. Error) }\end{array}$ & $\mathbf{p}$ \\
\hline Kadın & 257 & 1,821 & 0,044 & 0,012 \\
Erkek & 196 & 1,653 & 0,049 & \\
\hline
\end{tabular}

Soru analizinde elde edilen p değeri 0,012 bulunmuş olup bu soru için cinsiyet anlamında istatistiksel olarak anlamlı bir fark tespit edilmiştir $(\mathrm{p}<0,05)$. Kadın öğretmenlerin puan ortalaması $(1,821 \pm 0,044)$ erkek öğretmenlerin puan ortalamasından $(1,653 \pm 0,049)$ büyük olduğu için kadın öğretmenlerin, erkek öğretmenlere göre daha fazla iş sağlığı ve güvenliği kurallarına hassasiyet gösterdikleri saptanmıştır.

\section{Anket Sorularına İlişkin Tek Yönlü Varyans Analizi}

\section{(One-Way Anova)}

Yaş seviyeleri arasındaki farklılı̆̆ın anlamlı olup olmadığını analiz etmek için parametrik testlerden Tek Yönlü 
Varyans Analizi testi katılımcılara uygulanmış ve testin sonucunda elde edilen p değeri > 0,05 anlamlılık düzeyinde ise; H0 hipotezi kabul edilip, yaş değişkeni seviyeleri arasında sorulan soru bakımından istatistiksel olarak anlamlı bir farklılık olmadığı sonucuna varılır. Eğer p değeri $<0,05$ anlamlılık düzeyinde ise; H0 hipotezi reddedilir ve yaş değişkeni seviyeleri arasında istatistiksel olarak anlamlı farklılık vardır. Elde edilen farklılığın hangi alt gruplar arasında olduğunu tespit etmek için Çoklu Karşılaştırma (Post Hoc) testlerinde Duncan testi tercih edilmiştir.

"İş kazası sonucunda ne yapılması gerektiği hakkında bilgi düzeyi” değişkeni ile yaş aralığı arasında farklılık yoktur (H0) ile anlamlı bir farklılık vardır (H1) hipotezleri için yapılan çalışma sonucunda elde edilen değerler Tablo 5'de verilmiştir.

Tablo 5: İş kazası sonucunda ne yapılması gerektiği hakkında bilgi düzeyi değişkenin yaş aralığına göretek yönlü varyans analiz sonuçları

\begin{tabular}{|c|c|c|c|c|c|c|}
\hline \multirow{2}{*}{$\begin{array}{l}\text { Yaş } \\
\text { Aralığı }\end{array}$} & \multirow{2}{*}{$\mathbf{n}$} & \multirow{2}{*}{$\overline{\mathbf{x}}$} & \multirow{2}{*}{$\begin{array}{c}\text { Standart Hata } \\
\text { (Std.Error) }\end{array}$} & \multicolumn{2}{|c|}{ Subset for alpha $=0,05$} & \multirow{2}{*}{$\mathbf{p}$} \\
\hline & & & & 1 & 2 & \\
\hline $22-32$ & 64 & 2,765 & 0,010 & 2,765 & & \multirow{4}{*}{0,028} \\
\hline $33-43$ & 206 & 2,825 & 0,049 & 2,825 & & \\
\hline $44-54$ & 160 & 2,981 & 0,057 & 2,981 & 2,981 & \\
\hline $55-65$ & 31 & 3,129 & 0,013 & & 3,129 & \\
\hline
\end{tabular}

İş kazası sonucunda ne yapılması gerektiği hakkındaki bilgi düzeyleri için anlamlılık değeri $\mathrm{p}=0,028<0,05$ elde edilmiştir. Dolayısıyla yaş seviyelerinde istatistiksel olarak anlamlı bir farklılık tespit edilmiştir. Grupların varyansları p>0,05 olduğu için varyanslar homojen çıkmıştır. Bu analize göre puan ortalamaları incelendiğinde, 22-32 yaş aralığının puan ortalaması $(2,765)$ en düşük düzeyde iken, 55-65 yaş aralığının puan ortalaması $(3,129)$ en yüksek düzeydedir. Farklılığın düzeyi ise en düşük seviden en yüksek seviyeye doğru bir artış gösterdiğinden öğretmenlerde yaşın ilerlemesiyle birlikte iş kazası sonucunda ne yapılması gerektiği hakkındaki bilgi düzeylerinin de arttığı söylenebilir.
Katılımcıların "okullarındaki iş güvenliği ile ilgili riskler hakkında bilgi düzeyi” değişkeni yaş aralığına göre farklılık yoktur (H0) ile anlamlı farklılık vardır (H1) hipotezleri için yapılan çalışma sonucunda elde edilen değerler Tablo 6’da verilmiştir.

Tablo 6: Katılımcıların okullarındaki iş güvenliği ile ilgili riskler hakkında bilgi düzeyi değişkeni yaş aralığına görefarklılığı için yapılan bağımsız tek yönlü varyans analiz sonuçları

\begin{tabular}{|c|c|c|c|c|c|c|}
\hline \multirow{2}{*}{$\begin{array}{c}\text { Yaş } \\
\text { Aralığı }\end{array}$} & \multirow{2}{*}{$\mathbf{n}$} & \multirow{2}{*}{$\overline{\mathbf{x}}$} & \multirow{2}{*}{$\begin{array}{l}\text { Standart Hata } \\
\text { (Std.Error) }\end{array}$} & \multicolumn{2}{|c|}{ Subset for alpha $=0,05$} & \multirow{2}{*}{$\mathbf{p}$} \\
\hline & & & & 1 & 2 & \\
\hline $22-32$ & 64 & 2,843 & 0,092 & 2,843 & & \\
\hline $33-43$ & 206 & 2,912 & 0,048 & 2,912 & 2,912 & 0,007 \\
\hline $44-54$ & 160 & 3,118 & 0,052 & & 3,118 & 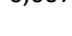 \\
\hline $55-65$ & 31 & 3,129 & 0,120 & & 3,129 & \\
\hline
\end{tabular}

Katılımcıların okullarındaki iş güvenliği ile ilgili riskler hakkında bilgi düzeyleri için anlamlılık değeri $\mathrm{p}<0,05$ elde edilmiştir. Dolayısıyla yaş seviyelerinde istatistiksel olarak anlamlı bir farklılık tespit edilmiştir. Bu analize göre puan ortalamaları incelendiğinde, 22-32 yaş aralığının puan ortalaması $(2,843)$ en düşük düzeyde iken, bunu sırasıyla 3343 yaş aralığı puanı (2,912), $44-54$ yaş aralı̆̆ı puanı $(3,118)$ ve $55-65$ yaş aralığı puan $(3,129)$ ortalaması takip etmektedir. Sonuç olarak farklılık düzeyi en düşük yaş seviyesinden en yüksek yaş seviyesine doğru bir artış gösterdiğinden öğretmenlerde yaşın ilerlemesiyle birlikte okullarındaki iş güvenliği ile ilgili riskler hakkındaki bilgi düzeylerinin de arttı̆̆ı söylenebilir.

\section{E. Anket Sorularına İlişkin Çapraz (Crosstabs) Tablo} Analizi

İki kategorik değişken arasındaki ilişki çapraz tablo ile ortaya konulabilir. Çapraz tablolarda değişkenler arasında ilişkinin olup olmadığı ya da ilişkinin hangi boyutta (zayıf, orta, güçlü) olduğunu belirlemek, değişkenlerin başka değişkenler üzerindeki etkisini göstermek, grubun dağılımını göstermek ve ortaya çıkmış olan alt grupların bütün içindeki dağılımlarını göstermek amacıyla yapılmaktadır [15]. "İş 
Tablo 7: "İşs sağlı̆̆ı ve güvenliği eğitimlerinin okullardaki riskleri azaltabileceğine inanıyorum" sorusu ile "Liselerde seçmeli olan iş sağ lı̆̆ı ve güvenliği dersi zorunlu ders olarak okutulmalıdır" sorusu arasındaki çapraz tablolama sonuçları

\begin{tabular}{|c|c|c|c|c|c|c|}
\hline \multirow[b]{2}{*}{$\begin{array}{l}\text { İş sağlığı ve güvenliği eğitimlerinin okullar- } \\
\text { daki riskleri azaltabileceğine inanıyorum. }\end{array}$} & \multicolumn{6}{|c|}{ Liselerde seçmeli olan iş sağlığı ve güvenliği dersi zorunlu ders olarak okutulmalıdır. } \\
\hline & $\begin{array}{l}\text { Tamamen } \\
\text { Katilıyorum }\end{array}$ & Katllıyorum & Kararsızım & Katilmıyorum & $\begin{array}{l}\text { Tamamen } \\
\text { Katilmıyorum }\end{array}$ & Toplam \\
\hline Tamamen & 113 & 50 & 29 & 9 & 3 & 204 \\
\hline Katilıyorum & $\% 55,4$ & $\% 24,5$ & $\% 14,2$ & $\% 4,4$ & $\% 1,5$ & $\% 100,0$ \\
\hline \multirow{2}{*}{ Katilıyorum } & 29 & 116 & 52 & 17 & 1 & 215 \\
\hline & $\% 13,5$ & $\% 54,0$ & $\% 24,2$ & $\% 7,9$ & $\% 0,5$ & $\% 100,0$ \\
\hline \multirow{2}{*}{ Kararsızım } & 1 & 6 & 11 & 2 & 0 & 20 \\
\hline & $\% 5,0$ & $\% 30,0$ & $\% 55,0$ & $\% 10,0$ & $\% 0,0$ & $\% 100,0$ \\
\hline \multirow{2}{*}{ Katilmıyorum } & 1 & 2 & 2 & 4 & 3 & 12 \\
\hline & $\% 8,3$ & $\% 16,7$ & $\% 16,7$ & $\% 33,3$ & $\% 25,0$ & $\% 100,0$ \\
\hline Tamamen & 0 & 3 & 0 & 1 & 1 & 5 \\
\hline Katılmıyorum & $\% 0,0$ & $\% 60,0$ & $\% 0,0$ & $\% 20,0$ & $\% 20,0$ & $\% 100,0$ \\
\hline \multirow{2}{*}{ Toplam } & 144 & 177 & 94 & 33 & 8 & 456 \\
\hline & $\% 31,6$ & $\% 38,8$ & $\% 20,6$ & $\% 7,2$ & $\% 1,8$ & $\% 100,0$ \\
\hline
\end{tabular}

sağlığı ve güvenliği eğitimlerinin okullardaki riskleri azaltabileceğine inanıyorum" sorusu ile "Liselerde seçmeli olan iş sağlığı ve güvenliği dersi zorunlu ders olarak okutulmalıdır” sorusu arasındaki çapraz tablolama sonuçları Tablo 7'de verilmiştir.

Ki-kare değerinin istatistiksel olarak anlamllık değeri 0,000 çıkmıştır. $\mathrm{p}<0,05$ olduğundan "İSG eğitimlerinin okullardaki riskleri azaltabileceğine inanıyorum.” önermesi ile "Liselerde seçmeli olan İSG dersi zorunlu ders olarak okutulmalıdır." önermesi arasında istatistiksel olarak anlamlı bir ilişki bulunmuştur. Bu sonuçlara göre "İş sağlı̆̆ı ve güvenliği eğitimlerinin okullardaki riskleri azaltabileceğine inanıyorum." ile "Liselerde seçmeli olan İSG dersi zorunlu ders olarak okutulmalıdır." önermelerinde öğretmenlerden 116 kişinin "Katıllyorum" seçeneğinde yoğunlaştı̆̆ı tespit edilmiştir. Elde edilen bu sonuca göre; öğretmenler, iş sağlığı ve güvenliğine yönelik verilecek eğitimin riskleri azaltabileceğine katıldığı söylenebilir.

"İş sağlığı ve güvenliğinin çalışma hayatımızı doğrudan etkilediğini düşünüyorum" sorusu ile "İşs sağlığı ve güvenliğinin sadece okul ortamında değil hayatın her aşamasında olması gerektiğini düşünüyorum” sorusu arasındaki çapraz tablolama sonuçları Tablo 8'de verilmiştir.

Ki-kare değerinin istatistiksel olarak anlamllık değeri 0,000 çıkmıştır. $\mathrm{p}<0,05$ olduğundan "İSG'nin çalışma hayatımızı doğrudan etkilediğini düşünüyorum.” önermesi ile "İşs sağlığı ve güvenliğinin sadece okul ortamında değil hayatın her aşamasında olması gerektiğini düşünüyorum." önermesi arasında istatistiksel olarak anlamlı bir ilişki bulunmuştur. Bu sonuçlara göre, "İşs sağlığı ve güvenliğinin sadece okul ortamında değil hayatın her aşamasında olması gerektiğini düşünüyorum." ile "İşs sağlığı ve güvenliğinin çalışma hayatımızı doğrudan etkilediğini düşünüyorum." önermelerine çalışmaya katılan öğretmenlerden 186 kişinin "Tamamen Katıllyorum" seçeneğinde yoğunlaştığı tespit edilmiştir.

Ki-kare değerinin istatistiksel olarak anlamllık değeri 0,012 çıkmışıtır. $\mathrm{p}<0,05$ olduğundan "İş kazası sonucunda ne yapılması gerektiği hakkında bilgi düzeyiniz nedir?’ önermesi ile "İşs sağlığı ve güvenliği eğitimi aldınız mı?" önermesi arasında istatistiksel olarak anlamlı bir ilişki bulunmuştur (Tablo 9). Bu sonuçlara göre, İSG eğitimi alan- 
Tablo 8: "İş sağlığı ve güvenliğinin çalışma hayatımızı doğrudan etkilediğini düşünüyorum” sorusu ile

"İş sağlı̆̆ı ve güvenliğinin sadece okul ortamında değil hayatın her aşamasında olması gerektiğini düşünüyorum" sorusu arasındaki çapraz tablolama sonuçları

\begin{tabular}{|c|c|c|c|c|c|c|}
\hline & & $\begin{array}{r}\text { İş sağlığı ve } \\
\text { her aş }\end{array}$ & $\begin{array}{l}\text { nliğinin sad } \\
\text { sında olmas }\end{array}$ & $\begin{array}{l}\text { okul ortamınd } \\
\text { rektiğini düşün }\end{array}$ & $\begin{array}{l}\text { değil hayatın } \\
\text { gorum. }\end{array}$ & \\
\hline $\begin{array}{l}\text { İş sağlığı ve güvenliğinin çalışma hayatımızı } \\
\text { doğrudan etkilediğini düşünüyorum. }\end{array}$ & $\begin{array}{l}\text { Tamamen } \\
\text { Katilıyorum }\end{array}$ & Katilıyorum & Kararsızım & Katılmıyorum & $\begin{array}{l}\text { Tamamen } \\
\text { Katılmıyorum }\end{array}$ & Toplam \\
\hline Tamamen & 186 & 10 & 0 & 0 & 0 & 196 \\
\hline Katilıyorum & $\% 94,9$ & $\% 5,1$ & $\% 0,0$ & $\% 0,0$ & $\% 0,0$ & $\% 100,0$ \\
\hline Katılıyorum & $\begin{array}{c}74 \\
\% 33,8\end{array}$ & $\begin{array}{c}141 \\
\% 64,4\end{array}$ & $\begin{array}{c}4 \\
\% 1,8\end{array}$ & $\begin{array}{c}0 \\
\% 0,0\end{array}$ & $\begin{array}{c}0 \\
\% 0,0\end{array}$ & $\begin{array}{c}219 \\
\% 100,0\end{array}$ \\
\hline Kararsızım & $\begin{array}{c}5 \\
\% 17,9\end{array}$ & $\begin{array}{c}16 \\
\% 57,1\end{array}$ & $\begin{array}{c}5 \\
\% 17,9\end{array}$ & $\begin{array}{c}2 \\
\% 7,1\end{array}$ & $\begin{array}{c}0 \\
\% 0,0\end{array}$ & $\begin{array}{c}28 \\
\% 100,0\end{array}$ \\
\hline Katilmıyorum & $\begin{array}{c}2 \\
\% 18,2\end{array}$ & $\begin{array}{c}4 \\
\% 36,4\end{array}$ & $\begin{array}{c}2 \\
\% 18,2\end{array}$ & $\begin{array}{c}1 \\
\% 9,1\end{array}$ & $\begin{array}{c}2 \\
\% 18,2\end{array}$ & $\begin{array}{c}11 \\
\% 100,0\end{array}$ \\
\hline $\begin{array}{l}\text { Tamamen } \\
\text { Katilmıyorum }\end{array}$ & $\begin{array}{c}0 \\
\% 0,0\end{array}$ & $\begin{array}{c}0 \\
\% 0,0\end{array}$ & $\begin{array}{c}0 \\
\% 0,0\end{array}$ & $\begin{array}{c}1 \\
\% 20,0\end{array}$ & $\begin{array}{c}4 \\
\% 80,0\end{array}$ & $\begin{array}{c}5 \\
\% 100,0\end{array}$ \\
\hline Toplam & $\begin{array}{c}267 \\
\% 58,2\end{array}$ & $\begin{array}{c}171 \\
\% 37,3\end{array}$ & $\begin{array}{c}11 \\
\% 2,4\end{array}$ & $\begin{array}{c}4 \\
\% 0,9\end{array}$ & $\begin{array}{c}6 \\
\% 1,3\end{array}$ & $\begin{array}{c}459 \\
\% 100,0\end{array}$ \\
\hline
\end{tabular}

lardan ( $\mathrm{n}=461) 206$ kişinin, iş kazası sonucunda ne yapılması gerektiği hakkında bilgi düzeylerinin "Orta" seviyede oldukları tespit edilmiştir. Buradan hareketle katılımcıların büyük çoğunluğunun İSG bilgi düzeylerinin "Orta" ve "Çok" seviyede olmasında daha önce almış oldukları İSG eğitiminin bir sonucu olarak ortaya çıktığı söylenebilir.

Tablo 9: "İş kazası sonucunda ne yapılması gerektiği hakkında bilgi düzeyiniz nedir?” sorusu ile "İş sağlığı ve güvenliği eğitimi aldınız mı?” sorusu arasındaki çapraz tablolama sonuçları

\begin{tabular}{lccc}
\hline & \multicolumn{3}{c}{ iş̧ sağlı̆ı ve güvenliği eğitimi aldınız mı? } \\
\hline $\begin{array}{l}\text { iş kazası sonucunda ne yapıl- } \\
\text { ması gerektiği hakkında bilgi } \\
\text { düzeyiniz nedir? }\end{array}$ & Evet & Hayır & Toplam \\
\hline Hiç & 5 & 2 & 7 \\
\hline \multirow{2}{*}{ Az } & $\% 71,4$ & $\% 28,6$ & $\% 100,0$ \\
\hline \multirow{2}{*}{ Orta } & 113 & 20 & 133 \\
\hline \multirow{2}{*}{ Çok } & $\% 85,0$ & $\% 15,0$ & $\% 100,0$ \\
\hline \multirow{2}{*}{ Toplam } & 206 & 19 & 225 \\
& $\% 91,6$ & $\% 8,4$ & $\% 100,0$ \\
\hline & 92 & 4 & 96 \\
& $\% 95,8$ & $\% 4,2$ & $\% 100,0$ \\
\hline
\end{tabular}

Ki-kare değerinin istatistiksel olarak anlamlılık değeri 0,000 çıkmıştır. $\mathrm{p}<0,05$ olduğundan "Tüm çalışanlar işe başlamadan önce iş sağlığı ve güvenliği eğitimi alması gerektiğini düşünüyorum.” önermesi ile "İşs sağlığı ve güvenliği eğitimlerinin okullardaki riskleri azaltabileceğine inanıyorum.” önermesi arasında istatistiksel olarak anlamlı bir ilişki bulunmuştur (Tablo 10).

Bu sonuçlara göre, "İşs sağlığı ve güvenliği eğitimlerinin okullardaki riskleri azaltabileceğine inanıyorum.” ile “Tüm çalışanlar işe başlamadan önce "İş sağlı̆̆ ve güvenliği eğitimi alması gerektiğini düşünüyorum.” önermelerinde çalışmaya katılan öğretmenlerden 184 kişinin “Tamamen Katılıyorum" seçeneğinde yoğunlaştığ 1 tespit edilmiştir.

Ki-kare değerinin istatistiksel olarak anlamlılık değeri 0,000 çıkmıştır. $\mathrm{p}<0,05$ olduğundan “Okulunuzda iş güvenliği ile ilgili riskler hakkında bilgi düzeyiniz nedir?’ önermesi ile "Okulumuzda iş sağlığı ve güvenliği konusunda sürekli iyileştirmeler yapılıyor.” önermesi arasında istatistiksel olarak anlamlı bir ilişki bulunmuştur (Tablo 11).

Bu sonuçlara göre, "Okulumuzda iş sağllğ̆ ve güvenliği konusunda sürekli iyileştirmeler yapılıyor.” önermesine 
Tablo 10: "Tüm çalışanlar işe başlamadan önce iş sağlığı ve güvenliği eğitimi alması gerektiğini düşünüyorum” sorusu ile "İş sağlığı ve güvenliği eğitimlerinin okullardaki riskleri azaltabileceğine inanıyorum” sorusu arasındaki çapraz tablolama sonuçları

\begin{tabular}{|c|c|c|c|c|c|c|}
\hline \multicolumn{7}{|c|}{ İş sağlığı ve güvenliği eğitimlerinin okullardaki riskleri azaltabileceğine inanıyorum. } \\
\hline $\begin{array}{l}\text { Tüm çalışanlar işe başlamadan önce iş sağlı- } \\
\text { ğı ve güvenliği eğitimi alması gerektiğini } \\
\text { düşünüyorum. }\end{array}$ & $\begin{array}{l}\text { Tamamen } \\
\text { Katilıyorum }\end{array}$ & Kattlıyorum & Kararsızım & Katılmıyorum & $\begin{array}{c}\text { Tamamen } \\
\text { Katilmıyorum }\end{array}$ & Toplam \\
\hline Tamamen & 184 & 74 & 9 & 3 & 1 & 271 \\
\hline Katilıyorum & $\% 67,9$ & $\% 27,3$ & $\% 3,3$ & $\% 1,1$ & $\% 0,4$ & $\% 100,0$ \\
\hline \multirow{2}{*}{ Katilıyorum } & 21 & 131 & 6 & 4 & 1 & 163 \\
\hline & $\% 12,9$ & $\% 80,4$ & $\% 3,7$ & $\% 2,5$ & $\% 0,6$ & $\% 100,0$ \\
\hline \multirow{2}{*}{ Kararsızım } & 1 & 8 & 5 & 1 & 0 & 15 \\
\hline & $\% 6,7$ & $\% 53,3$ & $\% 33,3$ & $\% 6,7$ & $\% 0,0$ & $\% 100,0$ \\
\hline \multirow{2}{*}{ Katılmıyorum } & 1 & 1 & 0 & 2 & 0 & 4 \\
\hline & $\% 25,0$ & $\% 25,0$ & $\% 0,0$ & $\% 50,0$ & $\% 0,0$ & $\% 100,0$ \\
\hline Tamamen & 0 & 1 & 0 & 2 & 3 & 6 \\
\hline Katilmıyorum & $\% 0,0$ & $\% 16,7$ & $\% 0,0$ & $\% 33,3$ & $\% 50,0$ & $\% 100,0$ \\
\hline \multirow{2}{*}{ Toplam } & 207 & 215 & 20 & 12 & 5 & 459 \\
\hline & $\% 45,1$ & $\% 46,8$ & $\% 4,4$ & $\% 2,6$ & $\% 1,1$ & $\% 100,0$ \\
\hline
\end{tabular}

katılan 135 kişi aynı zamanda görev yaptığı okullarda iş güvenliği ile ilgili riskler hakkında bilgi düzeylerinin "Orta” seviyede olduğu tespit edilmiştir.

\section{SONUÇ VE ÖNERİLER}

Bu çalışmada, Çanakkale ili merkez ve ilçelerinde ortaöğretim okullarında görev yapan öğretmenlerin yürürlükte olan İSG mevzuatının getirdiği düzenlemeler ve yükümlülüklere ilişkin iş güvenliğgi bilgi düzeyleri incelenmiştir. İnceleme neticesinde öğretmenlerin okullarının bünyesinde var olan iş güvenliği ile ilgili tehlikeler ve riskler, iş kazaları ve meslek hastalıkları, olası bir deprem ve yangın esnasında yapılması gerekler hakkındaki bilgi düzeylerinin "orta” ve “çok” seviye arasında olduğu görülmüştür. Buna karşın iş kazaları sonucunda yapılacak ilk yardım uygulamaları ile iş kazası sonucunda ne yapılması gerektiği hususundaki bilgi düzeyleri ise "az" ve "orta” seviyede oldukları görülmüştür. Öğretmenlerin ilk yardım bilgi seviyelerinin hizmet içi eğitim üzerinden yapılacak uygulamalar ile artırılabilme imkânı vardır.
Öğretmenlerin \%25’i okullarının hangi tehlike sınıfında yer aldığını bilmedikleri, \%30'unun okullarında kısmi zamanlı iş güvenliği uzmanının görevlendirildiğini bilmedikleri, \%44'nün ise görevlendirilmediklerini belirttikleri görülmüştür. Oysa okullarında görevlendileren kısmi zamanlı iş güvenliği uzmanı bulunmaktadır. Dolayısyla öğretmenlerin yaklaşık \%75'i bu soru hakkında doğru bilgiye sahip olmadığı söylenebilir.

Öğretmenlerin yaklaşık \%80'ni okullarında yangın alarm sistemi olduğunu ve olası bir acil duruma karşı eylem planının olduğunu belirtmişlerdir. Öğretmenlerin yaklaşık \%50'si okullarında İSG kurulu olduğunu, yaklaşı \%80'ni yangınla mücadele ekipmanlarının (yangın tüpü, yangın hortumu) olduğunu, \%44'nün ise okullarında risk değerlendirme ekiplerinin olduğunu belirtmişlerdir. Öğretmenlerin \%39’u ise okullarında risk değerlendirme analizi yapılıp yapılmadığını bilmediklerini belirtmişlerdir.

Yapılan değerlendirmeler sonucunda; iş sağlığı ve güvenliği eğitimlerinin okullardaki riskleri azaltabileceğine inanan öğretmenlerin oranının \%46.4 olduğu, liselerde 
seçmeli olan iş sağlığı ve güvenliği dersi zorunlu ders olmalıdır diyenlerin oranının \%38,4 olduğu, liselerde iş sağlığı ve güvenliği bölümünün açılmasının gerekli olduğunu düşünenlerin oranının ise $\% 38,0$ olduğu tespit edilmiştir.

Öğretmenler, iş kazasının nedenlerinin "Dikkatsizlik", "İhmal" ve "Eğitimsizlik" olduğunu belirtmişlerdir. Bu da İSG literetüründe iş kazaları nedenlerinin en büyük sebebi kişisel nedenler olduğu görüşü ile paralellik göstermektedir.

Öğretmenlerin okullarındaki sağlık ve güvenlik işaretlerinin ne anlama geldiği hakkında bilgi düzeyi ile cinsiyet arasında istatistiksel olarak anlamlı bir ilişki bulunduğu, erkek öğretmenlerin kadın öğretmenlere göre okullarındaki sağlık ve güvenlik işaretlerinin ne anlama geldiği hakkındaki bilgi düzenlerinin daha yüksek olduğu tespit edilmiştir.

Aynı şekilde olası bir iş kazası, deprem ve yangın durumunda yapılması gerekenler hakkında bilgi düzeyi ile cinsiyet arasında istatistiksel olarak anlamlı bir ilişki bulunduğu, erkek öğretmenlerin kadın öğretmenlere göre olası bir iş kazası, deprem ve yangın durumunda ne yapılması gerektiği konusunda daha fazla bilgi sahibi oldukları ve yaşın ilerlemesiyle birlikte bilgi düzeylerinin de arttığı gözlemlenmiştir.

Her eğitim-öğretim yılında okullarımızda ve eğitim kurumlarımızda yaralanma veya ölümle sonuçlanan kazalar meydana gelmektedir. Bu kazaların önüne geçmek için tüm eğitim kademelerindeki öğrencilere İSG kuralları, iş kazaları ve meslek hastalıkları konularında eğitim verilmelidir. Bu kapsamda öğrencilerin İSG bilinç düzeylerinin arttırılması için İSG ile ilgili derslerin müfredata dahil edilmesi, mesleki ve teknik eğitim veren liselerde ise İSG bölümlerinin açılması atılması gereken adımların en başında gelmektedir.

Okullarda görev yapan tüm çalışanların İSG ile ilgili çalışmalarda görüş ve önerileri dikkate alınmalı, çalışanların sürece katılımları teşvik edilmeli, okullarda meydana gelen ramak kala olayları da dahil tüm kazalar kayıt altına alınıp analiz edilmeli, kazaların yaşanmaması için gerekli tedbirler önceden alınmalıdır.

İSG haftasında (4-10 Mayıs) öğretmen ve öğrencilerin hazırlayabileceği resim, afiş, broşür gibi görsel faaliyetlerin sergilenebileceği İSG panosu oluşturulması, tüm okul türlerinde ramak kala olay kutuları oluşturulması, okullarda iş sağlığı ve güvenliği kulüpleri oluşturulması, İSG uygulamalarına yer verilmesi okullarda bulunan tüm kişilerde farkındalıklar oluşturulması açısından oldukça önemlidir.

Mesleki ve teknik eğitim veren okullarda öğrencilere staj uygulamasına başlamadan önce iş çevresi ve iş ortamı hakkında bilgilendirmeler yapılıp eğitim verilmesi, oluşması muhtemel olan iş kazalarının önüne geçilerek azaltılabilir.

İSG ile ilgili ortam gözetimleri, önleyici tedbirler, rehberlik ve danışmanlık gibi hizmetleri sunmaları için İl ve İlçe Milli Eğitim Müdürlüklerinde oluşturulan "İşyeri Sağlık ve Güvenlik Birimleri/Büroları”nda iş güvenliği uzmanı olan öğretmenlerin okullarda görevlendirilmeleri, okul ve kurumların sağlıklı ve güvenli hale getirilmesi açısından oldukça önemlidir.

YAZAR KATKILARI: 1. yazar \%50, 2. yazar \%20, 3. yazar \%30 oranında katkı sağlamıştır.

ÇıKAR ÇATışması: Yazarlar herhangi bir çıkar çatışması olmadığını, makalede araştırma ve yayın etiğine uyulduğunu beyan ederler.

Finansal Destek: Bu çalışmada herhangi bir kişi, kurum veya kuruluştan finansal destek alınmamıştır.

Eтік Коміте Onayı: Çalışma için 20/02/2019 tarih ve 60305806-44-E.3530043 numarası ile Çanakkale İl Milli 
Eğitim Müdürlüğü Anket-Araştırma İnceleme Komisyonu tarafından onay alınmıştır.

\section{KAYNAKÇA}

[1] Bilir, N. (2016). İş Sağlığı ve Güvenliği Profili. Erişim Tarihi:21.12.2019, https://www.ilo.org/wcmsp5/ groups/public/---europe/---ro-geneva/---ilo-ankara/ documents/publication/wcms_498818.pdf

[2] MEB (2019). Milli Eğitim Bakanlığı Strateji Geliştirme Başkanlığı, Erişim Tarihi: 01.09.2019, http:// sgb.meb.gov.tr/www/icerik_goruntule.php? $\mathrm{KNO}=361$

[3] TÜİK (2020). Adrese Dayalı Nüfus Kayıt Sistemi Sonuçları 2019. Erişim Tarihi: 04.02.2020, http:// tuik.gov.tr/PreHaberBultenleri.do?id=33705

[4] Ersoy S. Sanayide Staj Yapan Meslek Lisesi Son Sınıf Öğrencilerinin İş güvenliği Konusunda Karşılaştıkları Sorunlar ve Çözüm Önerileri (Tez). Marmara Üniversitesi, Teknoloji Eğitimi Anabilim dalı Yüksek Lisans Tezi; 2004.

[5] Sekmen M. R. Endüstriyel Teknik Lise Elektrik Bölümlerinde Okuyan Öğrencilerin Karşılaştıkları İş Güvenliği sorunları (Tez). Yetitepe Üniversitesi, Eğitim Yönetimi ve Denetimi Anabilim Dalı Yüksek Lisans Tezi; 2006.

[6] Yaman H. Gaziantep'teki Meksa-Gesop Çıraklık Eğitim Merkezindeki Kursiyerlerin İş Sağlığı ve İş Güvenliğine Bakışının Değerlendirilmesi (Tez). Gaziantep Üniversitesi, Hemşirelik Anabilim Dalı Yüksek Lisans Tezi; 2011.

[7] Aksoy, S., Çevik, B., ve Çakıcıer, N. (2013). Gümüşova Meslek Yüksekokulu’nda İş Güvenliği Bilincinin Belirlenmesi. Düzce Üniversitesi Bilim ve Teknoloji Dergisi, 1(1), 69-76.

[8] Uslu V. İşletmelerde İş Güvenliği Performansı ve İş Güvenliği Kültürü Algılamaları Arasındaki İlişki: Eskişehir ili Metal Sektöründe Bir Araştırma (Tez). Eskişehir Osmangazi Üniversitesi, İşletme Anabilim Dalı Yüksek Lisans Tezi; 2014.

[9] Gümüş B. Okullarda İş Sağlığı ve Güvenliği Uygulamaları ve Öğretmenlerin Bu Konudaki Bilgi Düzeylerinin İrdelenmesi (Tez). İstanbul Aydın Üniversitesi, İş Sağlığı ve Güvenliği Anabilim Dalı Yüksek Lisans Tezi; 2016.

[10] Beşir A. Devlet Okullarında İş Sağlığı ve Güvenliği Kültürüne Yaklaşımın İncelenmesi: Şile Örneği (Tez). Üsküdar Üniversitesi, İş Sağlığı ve Güvenliği Anabilim Dalı Yüksek Lisans Tezi; 2018.
[11] Uzuntarla F. Sağlık Çalışanlarının İş Güvenliği farkındalıkları İle Güvenli Davranışları Arasındaki ilişkinin İncelenmesi (Tez). Çankaya Üniversitesi, İş Sağlığı ve İş Güvenliği Anabilim Dalı Yüksek Lisans Tezi; 2018.

[12] Yar N. S. İş sağlığı ve güvenliği uygulamalarının Çalışanların İş Sağlığı ve Güvenliği Farkındalığı Üzerine Etkilerinin İncelenmesi (Tez). Üsküdar Üniversitesi, İş Sağlığı ve Güvenliği Anabilim Dalı Yüksek Lisans Tezi; 2018.

[13] Sari H. Petrol Rafinerisi Çalışanlarının İş Güvenliğine İlişkin Görüşlerinin Analizi (Mersin Ataş Örneği) (Tez). Çukurova Üniversitesi, İş Sağlığı ve Güvenliği Anabilim Dalı Yüksek Lisans Tezi; 2019.

[14] Tavşancıl, E. (2019). Tutumların Ölçülmesi ve SPSS ile Veri Analizi. 6. Baskı, Ankara, Nobel Akademik Yayıncilık.

[15] Özbay Ö. (2008), Çapraz Tablo Analizi Nasıl Yapılır? Pratik Bir Açıklama, Hacettepe Üniversitesi Türkiyat Araştırmaları (HÜTAD), 9, 459-470. 